\title{
Strontium Isotope Stratigraphy: LOWESS Version 3: Best Fit to the Marine Sr-Isotope Curve for 0-509 Ma and Accompanying Look-up Table for Deriving Numerical Age
}

\author{
J. M. McArthur, R. J. Howarth, and T. R. Bailey ${ }^{1}$ \\ Geological Sciences, University College London, Gower Street, London WC1E 6BT, United Kingdom \\ (e-mail: j.mcarthur@ucl.ac.uk)
}

\begin{abstract}
A B S T R A C T
An improved and updated version of the statistical LOWESS fit to the marine ${ }^{87} \mathrm{Sr} /{ }^{86} \mathrm{Sr}$ record and a revised look-up table (V3:10/99; available from j.mcarthur@ucl.ac.uk) based upon it enables straightforward conversion of ${ }^{87} \mathrm{Sr} /{ }^{86} \mathrm{Sr}$ to numerical age, and vice versa, for use in strontium isotope stratigraphy (SIS). The table includes $95 \%$ confidence intervals on predictions of numerical age from ${ }^{87} \mathrm{Sr} /{ }^{86} \mathrm{Sr}$. This version includes the Triassic and Paleozoic record $(0-509$ $\mathrm{Ma}$ ) omitted from previous versions because of the paucity of adequate data at the time of preparation. We highlight differences between the previous versions of the table and the current version and discuss some aspects of the ${ }^{87} \mathrm{Sr} /{ }^{86} \mathrm{Sr}$ record that may have geological significance. We give examples of how the table can be used and where it has proven useful.
\end{abstract}

\section{Introduction}

We know in outline how marine ${ }^{87} \mathrm{Sr} /{ }^{86} \mathrm{Sr}$ has changed through Phanerozoic time (fig. 1; for reviews, see McArthur 1994; Veizer et al. 1997, 1999). The ${ }^{87} \mathrm{Sr} /{ }^{86} \mathrm{Sr}$ record can be used to date and correlate marine sediments (Hess et al. 1989; McArthur et al. 1992, 1993a; Gale et al. 1995; Sugarman et al. 1995; Dingle et al. 1997; Dingle and Lavelle 1998; Crame et al. 1999|, estimate the duration of stratigraphic gaps (Miller et al. 1988), underpin speculation about major geochemical cycles (Kump 1989; Berner and Rye 1991; Godderis and Francois 1995; Derry and France-Lanord 1996), estimate the duration of biozones (McArthur et al. 1993a, 2000b) and stages (Weedon and Jenkyns 1999|, and distinguish between marine and nonmarine environments (Schmitz et al. 1991; PoyatoAriza et al. 1998).

When assigning numerical ages to sediments or estimating the duration of a biozone or a sedimentary gap, the task is both easier and less prone to error if one can convert quickly and easily from ${ }^{87} \mathrm{Sr} /{ }^{86} \mathrm{Sr}$ to numerical age. Howarth and McArthur (1997) compiled ${ }^{87} \mathrm{Sr} /{ }^{86} \mathrm{Sr}$ data and fitted to them a

Manuscript received May 2, 2000; accepted October 3, 2000.

${ }^{1}$ Also at Geology, Royal Holloway University of London, Egham, Surrey TW20 0EX, United Kingdom. nonparametric LOWESS statistical regression function (LOcally WEighted Scatterplot Smoother of Cleveland 1979; Chambers et al. 1983; Thisted 1988; Cleveland et al. 1992). The resulting curve, with its $95 \%$ confidence intervals, was then converted into a simple table that gave numerical ages, and their $95 \%$ confidence limits, for any given ${ }^{87} \mathrm{Sr} /{ }^{86} \mathrm{Sr}$ value, the values being interpolated in steps of 0.000001. McArthur and Howarth (1998) updated the fit (V2:1/98) and added a second table for converting numerical ages to ${ }^{87} \mathrm{Sr} /{ }^{86} \mathrm{Sr}$ values. These tables have proven popular, so we now provide a third version, V3:10/99, that improves on earlier releases and covers the period 0-509 Ma. We document the data on which the fit is based and show how the table can best be used. The full table can be obtained by e-mail from j.mcarthur@ ucl.ac.uk.

\section{The LOWESS Isotopic Database}

Our V3:10/99 LOWESS model for the period 0-509 $\mathrm{Ma}$ (fig. 1) is based on 3366 data pairs from 42 published and four unpublished sources (table 1). For each source, we use only those data we believe to be accurate. We include data for conodonts only 

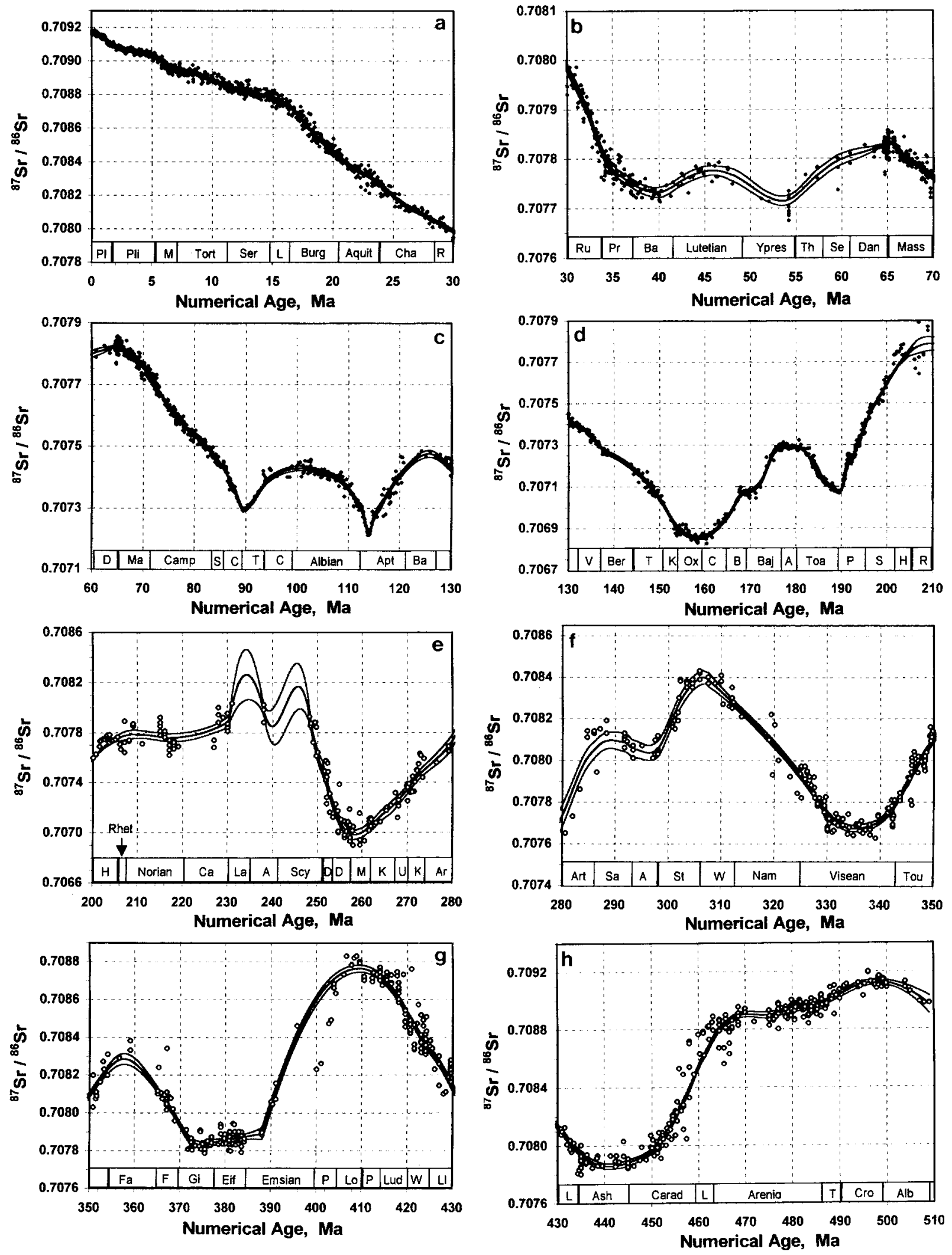

Figure 1. LOWESS fit for the period 0-509 Ma with $95 \%$ confidence bounds; see text for a discussion of its parts 
Table 1. Literature Sources for V3:10/99 (3366 Data Pairs)

\begin{tabular}{|c|c|c|c|c|}
\hline No. & Author & $\begin{array}{l}\text { Lab } \\
\text { no. }\end{array}$ & $\begin{array}{c}\text { Normalizer } \\
\left(\times 10^{6}\right)\end{array}$ & $\begin{array}{l}\text { Age range } \\
(\mathrm{Ma})\end{array}$ \\
\hline 31 & Banner and Kaufman 1994 & 11 & -3 & $342.1-336.7$ \\
\hline 32 & Bertram et al. 1992 (conodonts) & 7 & 11 & $414.0-429.6$ \\
\hline 30 & Bralower et al. 1997 (inoceramids) & 10 & 0 & 93.9-114.9 \\
\hline 33 & Bruckschen et al. $1995^{\mathrm{a}}$ & 12 & $17 ?$ & $327.5-353.7$ \\
\hline 16 & Callomon 2000 & 3 & 0 & $164.3-164.5$ \\
\hline 34 & Carpenter et al. 1991 & 13 & 3 & $367.0-367.0$ \\
\hline 22 & Clemens et al. 1993, 1995 & 4 & -9 & $.0-.2$ \\
\hline 35 & Cummins and Elderfield 1994 (brachiopods) & 7 & 11 & $325.0-328.5$ \\
\hline 23 & DePaolo and Ingram 1985 (Paleogene) & 5 & -59 & $38.5-65.0$ \\
\hline 27 & Denison et al. $1993^{\mathrm{a}}$ & 14 & 102 & $46.5-64.6$ \\
\hline 37 & Denison et al. $1994^{\mathrm{a}}$ & 14 & 102 & $252.0-350.8$ \\
\hline 38 & Denison et al. $1997^{a}$ & 14 & 102 & $354.0-430.8$ \\
\hline 39 & Denison et al. $1998^{\mathrm{a}}$ & 14 & 102 & $436.2-509.0$ \\
\hline 36 & Diener et al. 1996 (brachiopods) & 12 & 17 & $365.7-391.0$ \\
\hline 29 & M. Engkilde, pers. comm., 1998 & 9 & 0 & $144.3-180.4$ \\
\hline 21 & Farrell et al. 1995 & 4 & -9 & $.0-7.0$ \\
\hline 40 & Gao 1990; G. Gao, pers. comm., 1992a & 11 & 108 & $476.0-499.4$ \\
\hline 28 & Henderson et al. 1994 & 8 & 15 & $.0-.37$ \\
\hline 5 & Hodell et al. 1991 (not site 502) & 2 & 18 & $7.3-24.2$ \\
\hline 6 & Hodell and Woodruff 1994 & 2 & 18 & $10.7-24.1$ \\
\hline 26 & Jenkyns et al. 1995 & 6 & -12 & $98.9-120.7$ \\
\hline 25 & Jones et al. $1994 a, 1994 b$ & 6 & 22 & $100.5-206.2$ \\
\hline 41 & Koepnick et al. $1990^{\mathrm{a}}$ & 14 & 102 & $207.0-238.0$ \\
\hline 42 & Martin and Macdougall 1995 & 15 & -12 & $248.3-298.0$ \\
\hline 8 & Martin et al. 1999 (<13.8 Ma) & 2 & 18 & $5.0-13.8$ \\
\hline 10 & McArthur et al. $1993 b$ & 3 & 0 & $71.4-88.5$ \\
\hline 12 & McArthur et al. $1993 a$ & 3 & 0 & $69.4-83.9$ \\
\hline 11 & McArthur et al. 1994 & 3 & 0 & $68.8-98.0$ \\
\hline 20 & McArthur et al. 1998 & 3 & 0 & $64.6-67.5$ \\
\hline 13 & McArthur et al. $2000 b$ & 3 & 0 & $183.4-191.3$ \\
\hline 14 & J. M. McArthur and W. J. Kennedy, unpub. data & 3 & 0 & $96.0-107.5$ \\
\hline 15 & J. M. McArthur and P. F. Rawson, unpub. data & 3 & 0 & $130.2-138.0$ \\
\hline 17 & McArthur and Morton 2000 & 3 & 0 & $175.6-179.1$ \\
\hline 47 & J. M. McArthur and N. Janssen, unpub. data & 3 & 0 & $127-143$ \\
\hline 19 & Mc Laughlin et al. 1995 & 3 & 0 & $65.9-70.1$ \\
\hline 7 & Mead and Hodell 1995 & 2 & 18 & $18.5-46.2$ \\
\hline 1 & Miller et al. 1988 & 1 & -14 & $23.8-34.8$ \\
\hline 2 & Miller et al. 1991 & 1 & -14 & $9.0-24.5$ \\
\hline 24 & Montanari et al. $1991^{\mathrm{a}}$ & 5 & -59 & $28.9-36.2$ \\
\hline 43 & Montañez et al. $1996^{\mathrm{a}}$ & 11 & -6 & $496.1-499.9$ \\
\hline 3 & Oslick et al. 1994 (>16 Ma) & 1 & -14 & $16.0-25.3$ \\
\hline 44 & Qing et al. $1998^{\mathrm{a}}$ & 12 & 10 & $419.1-490.0$ \\
\hline 46 & Roark 1989 (in Carpenter et al. 1991) & $?$ & $0 ?$ & $365.0-379.0$ \\
\hline 45 & Ruppel et al. 1996 & $\dot{11}$ & -7 & $410.5-436.0$ \\
\hline 4 & Sugarman et al. 1995 & 1 & -14 & $65.1-65.8$ \\
\hline 9 & Zachos et al. 1992, 1999 & 15 & 0 & $24.0-43.2$ \\
\hline
\end{tabular}

${ }^{a}$ We used only some data from these publications.

where their color alteration index is no greater than 1 (e.g., Martin and Macdougall 1995) or where data would be so sparse without them as to compromise the curve fitting (Bertram et al. 1992; Ruppel et al. 1996; Qing et al. 1998). Data are corrected for interlaboratory bias mostly by adding or subtracting an amount considered necessary to make them concordant with either a value for SRM 987 (now NIST 987) of 0.710248 or a value for EN-1 of 0.709175 (table 1). Our normalizer (table 1) may be unique where we have assessed interlaboratory bias by means of an interlaboratory comparison or through independent analytical testing of data from published sources. Although residual bias exists after normalization to standards (Hodell and Woodruff 1994; McArthur 1994; Martin et al. 1999), our procedures attempt to minimize it.

The data used to compute V3 of the LOWESS curve differ from those used for $\mathrm{V} 2$ in the following respects: (1) Unlike V1 and V2, V3 includes data for the interval $206 \mathrm{Ma}$ (base of the Jurassic) to $509 \mathrm{Ma}$ (base of the Late Cambrian); data for older intervals 
are omitted because their age assignments are not well constrained. (2) The late Pliensbachian and early Toarcian part of the Jurassic curve has been revised after recognition that ammonite zones in this interval differed in duration by as much as a factor of 30 (McArthur et al. 2000b), a finding that affects the temporal calibration of the lower Toarcian biozonation (Jones et al. 1994b) used in earlier LOWESS fits. (3) The Bajocian-Aalenian boundary is supplemented with ${ }^{87} \mathrm{Sr} /{ }^{86} \mathrm{Sr}$ values for belemnites from the Auxiliary Stratotype Point at Berreriag, Isle of Skye (McArthur and Morton 2000). (4) The Callovian-Bathonian boundary is supplemented with ${ }^{87} \mathrm{Sr} /{ }^{86} \mathrm{Sr}$ values for belemnites from the proposed Global Stratotype Section and Point in southern Germany (Callomon 2000). (5) The Valenginian and Hauterivian are supplemented with further analyses of belemnites from France and Spain (J. M. McArthur and N. Janssen, unpub. data). (6) Data for the Cretaceous-Tertiary (K-T) boundary interval now include those of McArthur et al. (1998). (7) We revert to the practice, used for V1, of relying almost exclusively on Farrell et al. (1995) for data in the period 0-7 Ma because their data scatter less than do alternative data, because we have independently quantified the interlaboratory bias applicable to Farrell et al.'s data (table 1), and because the normalizer for the University of Florida data is uncertain to \pm 0.000005 (Hodell and Woodruff 1994; Martin et al. 1999). (8) For the reasons given in item 7 , and because we prefer modern data to pioneering older data, the following data, which were used in V2, are no longer used: Hess et al. (1986, 1989), Beets (1992), and for ages <6 Ma, Hodell et al. $(1989,1990,1991) ;$ O. G. Podlaha (pers. comm., 1997); and Oslick et al. (1994) for ages <16 $\mathrm{Ma}$, since we prefer the less scattered data from the University of Florida in the interval 6-10 Ma.

\section{Numerical Calibration}

The V3 fitted model (fig. 1) uses the time scales of Shackleton et al. (1995; 0-6.4 Ma), Berggren et al. (1995; 6.4-70 Ma, based on Cande and Kent 1995), Obradovich (1993; 70-98.5 Ma), Gradstein et al. (1995; 98.5-206 Ma), and Young and Laurie (1996; 206-509 Ma). Where original data (table 1) were reported to other time scales, the numerical ages have been converted using one of three methods: (1) the chart of Wei (1994; with corrections) for the period 0-7 Ma; (2) the formula of Wei (1994) and the temporally nearest pair of numerically dated stratigraphic tie-points accepted as good by the authors of the time scales to which we convert (e.g., in the Jurassic, the tie-points were the stage bound- ary ages of Gradstein et al. 1995); and (3) for the Triassic and older periods, biostratigraphical ages were converted to numerical ages using the time scale charts of Young and Laurie (1996), in all cases by reference to the finest biostratigraphic subdivisions given in the original publications, which were used to convert ages on a sample-by-sample basis. Table 2 gives the most important of the fixed time-ties. Calibration of the Phanerozoic time scale continues apace, and some of the ages used may already be outdated, but we have refrained from using new reported ages that have not yet gained widespread acceptance.

\section{The LOWESS Fit}

Details of how the LOWESS fit is derived are given in Howarth and McArthur (1997); we give here a brief nontechnical summary for those not conversant with the method. Values of ${ }^{87} \mathrm{Sr} /{ }^{86} \mathrm{Sr}$ were plotted on the $Y$-axis of a scatterplot against numerical age on the $X$-axis. A window incorporating a chosen fraction of the age data, for example, 0.05 (i.e., $5 \%$ ), was centered on a given datum. All data within the window were assigned weights that varied smoothly from unity, for the point with an $x$ value at the window center, to zero for points at the limits. Values of ${ }^{87} \mathrm{Sr} /{ }^{86} \mathrm{Sr}$ within the window were then fitted as a quadratic function of numerical age using weighted least squares regression. Residuals (i.e., predicted ${ }^{87} \mathrm{Sr} /{ }^{86} \mathrm{Sr}$ minus actual ${ }^{87} \mathrm{Sr} /{ }^{86} \mathrm{Sr}$ ) were calculated for each point in the window and used to assign new weights to each datum /data points with large residuals were downweighted), and the regression was repeated. This process was repeated until a final best-fit curve was obtained, and this final regression fit was used to calculate a single

Table 2. Principal Numerical Ages (Ma of the Base of Unit) Adopted for LOWESS V3:10/99

\begin{tabular}{lccc}
\hline Unit & Late & Middle & Early \\
\hline Pleistocene & .2 & .78 & 1.78 \\
Pliocene & 3.58 & $\ldots$ & 5.32 \\
Miocene & 11.2 & 16.4 & 23.8 \\
Oligocene & 28.5 & $\ldots$ & 33.7 \\
Eocene & 37.0 & 49.0 & 54.8 \\
Paleocene & 60.9 & $\ldots$ & 65.0 \\
Cretaceous & 98.5 & $\ldots$ & 142.0 \\
Jurassic & 159.4 & 180.1 & 205.7 \\
Triassic & 230 & 243 & 251 \\
Permian & 270 & $\ldots$ & 298 \\
Carboniferous & 325 & $\ldots$ & 354 \\
Devonian & 369 & 384 & 410 \\
Silurian & 420 & $\ldots$ & 434 \\
Ordovician & 459 & $\ldots$ & 490 \\
Cambrian, Late & 498 & 509 & $\ldots$ \\
\hline
\end{tabular}


best estimate of ${ }^{87} \mathrm{Sr} /{ }^{86} \mathrm{Sr}$ corresponding to the age at each window center and associated upper and lower $95 \%$ confidence limits on the estimated ${ }^{87} \mathrm{Sr} /{ }^{86} \mathrm{Sr}$ value. These three values were recorded, the window was moved one data point, and the entire process was repeated. For V3, this generated estimated values of ${ }^{87} \mathrm{Sr} /{ }^{86} \mathrm{Sr}$ for 3366 numerical ages and their associated confidence intervals. This ensemble of points constitutes the complete fit. Because of the complex shape of the fit and the uneven density of data in time, the curve was optimized by being fitted in 21 overlapping local segments. The segments were then joined using splines at segment junctions. The final array of points was then interpolated to obtain numerical age as a function of ${ }^{87} \mathrm{Sr} /{ }^{86} \mathrm{Sr}$.

\section{Discussion}

The LOWESS fit is shown in figure 1. The halfwidth of the $95 \%$ confidence interval on the estimated ${ }^{87} \mathrm{Sr} /{ }^{86} \mathrm{Sr}$ is plotted as a function of numerical age in figure $2 a$ and the rate of change with time of the fit in figure $2 b$. The half-width of the confidence interval in figure $2 a$ reflects both the density of data and the quality of analytical measurement and sample preservation. From 0 to $7 \mathrm{Ma}$ and from 65 to $90 \mathrm{Ma}$ (Late Cretaceous), the half-width is about 0.000004 , and it is nearly as low $(0.000005)$ in the late Pliensbachian and early Toarcian due to the high density of data in these intervals. From 7 $\mathrm{Ma}$, it steadily worsens with age to be \pm 0.000012 in the early Paleocene, where data are sparse. It is between 0.000007 and 0.000010 for much of the Jurassic and Cretaceous. Triassic data are very sparse and scattered; consequently, the half-width is between 0.000030 and 0.000140 for this interval. Data for the Permian are irregularly distributed in time, and the two data sets for this interval (Denison et al. 1994; Martin and Macdougall 1995) are a little discordant due to difficulties of temporal calibration and the effects of diagenetic overprint, so the half-width for the period is high, between 0.000032 and 0.000045 . For most of the remaining Phanerozoic, the half-width hovers between 0.000015 and 0.000020 , with brief excursions to higher values as a result of scarcity of data in the Fammenian (354-364 Ma) and in the Early Devonian (Emsian-Pragian-Lochkovian, 385-410 Ma). Figure $2 b$ shows that the rate at which ${ }^{87} \mathrm{Sr} /{ }^{86} \mathrm{Sr}$ changes with time has mostly been $<0.000050 /$ m.yr. Apparently higher rates in the Permo-Triassic probably reflect problems with age calibration, low sample density, and diagenetic overprinting.

The Attainable Quality of ${ }^{87} \mathrm{Sr} /{ }^{66} \mathrm{Sr}$ Measurement. It
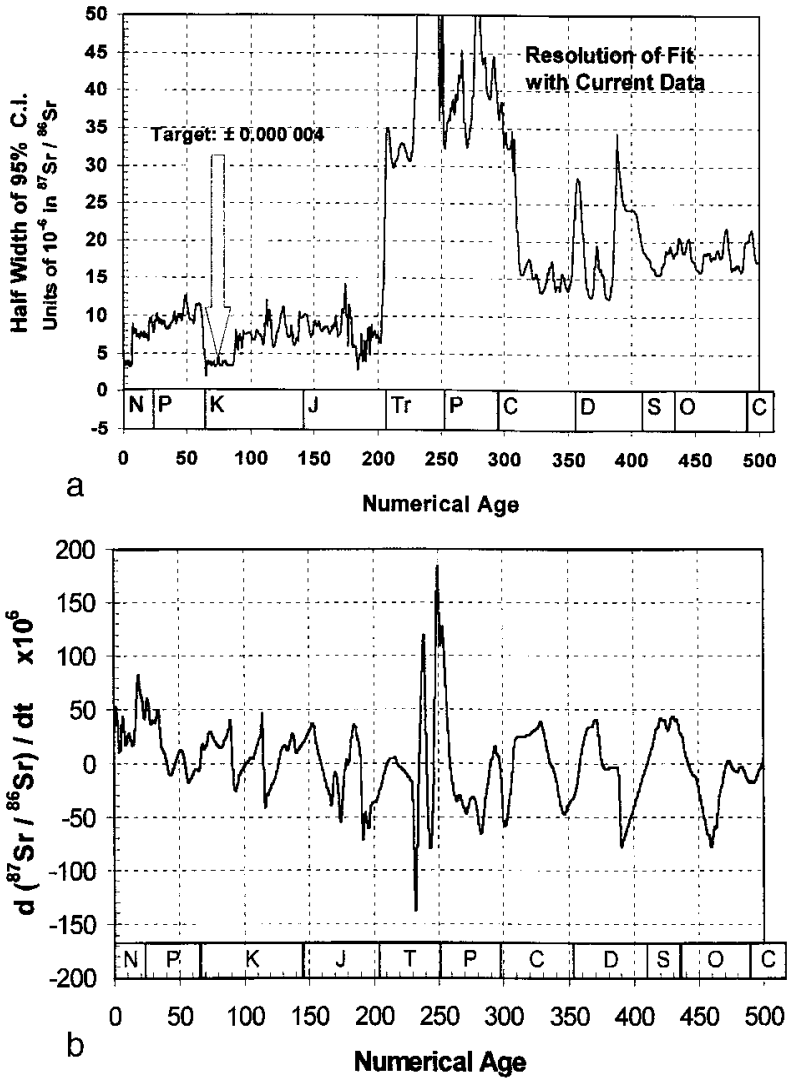

Figure 2. $a$, Half-width of the $95 \%$ confidence intervals on the LOWESS fit; $b$, rate of change with time of ${ }^{87} \mathrm{Sr} /{ }^{86} \mathrm{Sr}$.

is sometimes assumed that diagenetic alteration makes preservation of a sample's ${ }^{87} \mathrm{Sr} /{ }^{86} \mathrm{Sr}$ the determining factor in strontium isotope stratigraphy (SIS) and that this makes redundant the pursuit of better accuracy and precision in measurement of ${ }^{87} \mathrm{Sr} /{ }^{86} \mathrm{Sr}$, which are commonly reported with an analytical uncertainty of between \pm 0.000015 and \pm 0.000030 . Such uncertainty estimates are usually based on twice the value of the standard deviation (2 s.d.) of replicate analyses of a standard reference material (usually NIST 987, formerly known as SRM 987) or, less commonly, replicate analysis of samples. Such values represent the analytical uncertainty attainable on an individual (i.e., single) analysis. Replicate analysis of a single sample or, better still, multiple analysis of a suite of samples from a single stratigraphic level, can greatly reduce the real uncertainty with which the ${ }^{87} \mathrm{Sr} /{ }^{86} \mathrm{Sr}$ of a level is known. This was shown by Jones et al. $(1994 b)$, who reported 28 analyses of 12 belemnites from one bedding plane in the Pliensbachian Jamesoni zone of Dorset, United Kingdom. The 
Table 3. Calibration of NIST 987 against EN-1 at Royal Holloway University of London

\begin{tabular}{lccrr}
\hline & \multicolumn{2}{c}{ March 1998 } & \multicolumn{2}{c}{ August 1998 } \\
\cline { 2 - 3 } & \multicolumn{1}{c}{ EN-1 } & NIST 987 & EN-1 & NIST 987 \\
\hline Mean & .7091500 & .7102236 & .7091448 & .7102182 \\
Population 2 s.d. & .0000102 & .0000073 & .0000138 & .0000108 \\
Population 2 s.e. & .0000036 & .0000033 & .0000032 & .0000025 \\
Value of Student's $t$ & 2.84 & 3.50 & 2.44 & .000039 \\
s.e. at 95\% confidence interval & .0000051 & .0000058 & 19 & .0000031 \\
$n$ & 8 & 5 & .7091746 \\
EN-1 adjusted to a value of & & & .79 \\
\hline
\end{tabular}

mean and 2 s.d. of the measurements are 0.707298 and \pm 0.000013 , respectively. This uncertainty does not represent the certainty with which the mean ${ }^{87} \mathrm{Sr} /{ }^{86} \mathrm{Sr}$ is known; that is given by the formula

$$
\pm t_{1-\alpha / 2, n-1}(\text { s.d. } / \sqrt{n}) \text {, }
$$

where $t_{1-\alpha / 2, n-1}$ is the $100(1-\alpha / 2)$ th percentile of the Student $t$ distribution with $(n-1)$ degrees of freedom, $n$ is the number of measurements (28), and s.d. is the standard deviation. Choosing a 95\% level of confidence gives a value for $\alpha$ of 0.05 and a value of 2.373 for $t$ (for $n=28$, and so 27 degrees of freedom); the uncertainty on the mean is then \pm 0.0000029 . The $t$ factor corrects for the fact that the sample size is finite. Such correction is preferable to taking the uncertainty on the mean as equal to twice the standard error of the mean, irrespective of $n$. Thus, replicate measurement reduced uncertainty to as little as one-tenth that reported by some laboratories for a singlet measurement. In many cases, the uncertainty in measurement of ${ }^{87} \mathrm{Sr} /{ }^{86} \mathrm{Sr}$, not sample preservation, limits the temporal and stratigraphic resolution of SIS. It remains to be seen whether this situation persists when analytical precision improves a further order of magnitude, to 0.000002 for a singlet measurement, and the standard error of the mean correspondingly decreases to about 0.0000002 .

The stratigraphic resolution of SIS approaches that of ammonite biostratigraphy in upper Pliensbachian and lower Toarcian (Jurassic) rocks of the United Kingdom (McArthur et al. 2000b); in the Toarcian exaratum subzone, it surpasses it. In Antarctica, in parts of the Neogene (Dingle et al. 1997; Dingle and Lavelle 1998) and the Late Cretaceous (Crame et al. 1999; McArthur et al. 2000a), SIS correlates rocks far better than does biostratigraphy. Given that the slope of the curve of ${ }^{87} \mathrm{Sr} /{ }^{86} \mathrm{Sr}$ against time is often $>0.000020 / \mathrm{m}$.yr. (e.g., in the Early Miocene it is $0.000060 / \mathrm{m}$.yr.), a precision of better than \pm 0.15 m.yr. (in the early Miocene, of \pm 50 k.yr.) is now attainable if enough replicate analyses are undertaken to reduce uncertainty on the mean. There is evidently much unrealized potential in SIS for accurate dating and correlation.

Interlaboratory Bias. Such potential is limited by the problem of interlaboratory bias. The importance of accurately quantifying interlaboratory bias increases as analytical precision improves. Precise ${ }^{87} \mathrm{Sr} /{ }^{86} \mathrm{Sr}$ values can be obtained to \pm 0.000003 (Jones et al. 1994b; Crame et al. 1999; McArthur et al. $2000 a, 2000 b$ ), but ${ }^{87} \mathrm{Sr} /{ }^{86} \mathrm{Sr}$ values for EN-1 and NIST 987 differ between laboratories by more than 0.000003 (McArthur 1994) and this problem persists. Interlaboratory bias must be quantified to better than this degree of uncertainty if SIS is to realize its full potential, and this can be done only by undertaking interlaboratory intercalibrations. In two calibrations of EN-1 against NIST 987, carried out at the Radiogenic Isotope Laboratory, Royal Holloway University of London, the two standards were alternated within a turret and run sequentially and repetitively, on two occasions, to give the data in table 3.

The fact that analytical uncertainties as low as \pm 0.000003 can be obtained focuses attention on the values quoted for standards. Clemens et al. $(1993,1995)$ give a value of 0.710257 for SRM 987, and their data for the time interval 0-100 ka give a mean of 0.709180 for modern marine $\mathrm{Sr}$, so their data can be normalized to that used for our curve by subtracting a value between 0.000009 and 0.000005 . The difference is equal to the uncertainty in replicate measurement of ${ }^{87} \mathrm{Sr} /{ }^{86} \mathrm{Sr}$; our unpublished data suggest that 0.000009 is the preferred normalizer (table 1). Hodell et al. (1989, 1990, 1991) report standards at 0.709172 and 0.710235 . It is therefore unclear whether normalization should involve adding 0.000003 or 0.000013 to their data; indeed, independent analysis (J. M. McArthur, unpub. data) suggest that 0.000018 would be the best figure. Results from a third laboratory give standard values of 0.709150 and 0.710240 ; hence, either 0.000025 or 0.000008 could be used to normalize the data from this laboratory to our LOWESS data; 


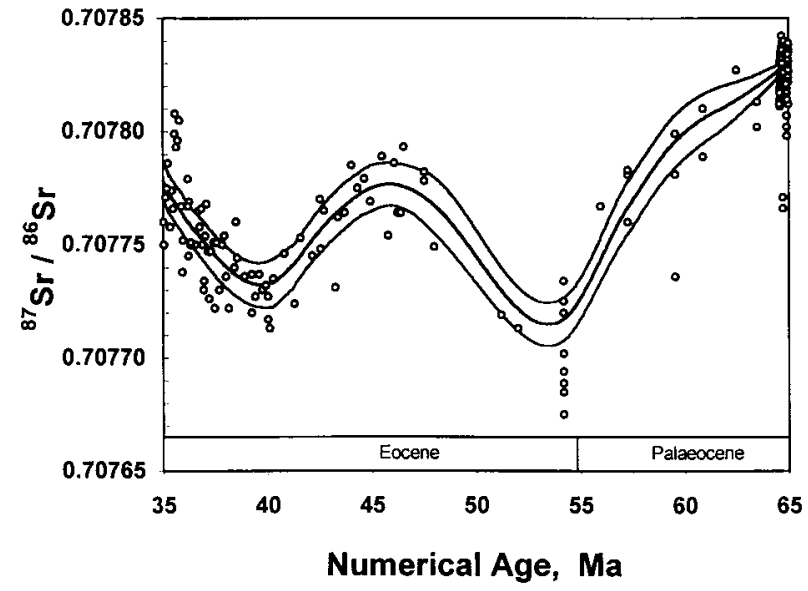

Figure 3. Tentative Paleogene trends in ${ }^{87} \mathrm{Sr} /{ }^{86} \mathrm{Sr}$. Mean line and $95 \%$ confidence intervals are shown. Data are sparse between 40 and $45 \mathrm{Ma}$ and very sparse between 45 and $64 \mathrm{Ma}$.

the difference of 0.000017 between these numbers is five times larger than the best attainable analytical precision. These observations suggest that improved accuracy and precision of measurement will do much to increase the impact and utility of SIS. One step to achieving these aims would be for laboratories engaged in SIS to participate in regular interlaboratory trials that generate data similar to that in table 3.

\section{Details of the LOWESS Fit}

Some details of the database and fit require comment. First, the ${ }^{87} \mathrm{Sr} /{ }^{86} \mathrm{Sr}$ curve for the Paleogene shows sufficient slope to be potentially useful for dating (fig. 3). From the K-T boundary (65 Ma) value of $0.70783,{ }^{87} \mathrm{Sr} /{ }^{86} \mathrm{Sr}$ declines to 0.70772 in the early Ypresian (55 Ma) before rising sharply to a maximum of 0.70778 in the middle Lutetian (46 Ma) and then declining again to a second minimum of 0.707730 in the early Bartonian (40 Ma). Thereafter, the ratio increases steeply until modern times. For the Paleocene, a resolution of \pm 0.000003 in ${ }^{87} \mathrm{Sr} /{ }^{86} \mathrm{Sr}$ measurement and a Paleocene ${ }^{87} \mathrm{Sr} /{ }^{86} \mathrm{Sr}$ decrease of around $0.000011 / \mathrm{m}$.yr. should give a temporal resolution of about $0.7 \mathrm{~m} . y \mathrm{r}$., when the ${ }^{87} \mathrm{Sr} /{ }^{86} \mathrm{Sr}$ curve is defined well enough to have confidence limits of \pm 0.000004 , the quality achieved for late Neogene (Farrell et al. 1995), Late Cretaceous (McArthur et al. 1993a), and Early Jurassic times (Pliensbachian-Toarcian; McArthur et al. 2000b).

Second, between 22 and $24 \mathrm{Ma}$, data scatter by up to 0.000180 (fig. 4). The scatter probably results from diagenesis in carbonate sequences, which was particularly prevalent at that time due to the abundance of discoasters that are readily overgrown with diagenetic calcite (W. Wise, pers. comm., 1998). Data in figure 4 were obtained by analysis of foraminifera. When using foraminifera, workers have relied on visual inspection and physical (rather than chemical) cleaning to remove contaminant phases. While physical cleaning is necessary, the best data come from samples for which acid leaching has removed the surface alteration and secondary calcite (McArthur 1994; Bailey et al. 2000; Reinhardt et al. 2000).

Third, around 230-245 Ma (in the Triassic; fig. 1e) the LOWESS fit is unreliable due to the paucity of data (this is the only part of our calibration curve where this occurs). Furthermore, in the early Permian, a number of points at 285-288 Ma plot high (fig. 1f), and we speculate that these data may have been affected by diagenetic processes. We note also that the sharpest and greatest change in ${ }^{87} \mathrm{Sr} /{ }^{86} \mathrm{Sr}$ $(\approx 0.000140 / \mathrm{m}$.yr.) occurred during Late PermianEarly Triassic time, when it was more than twice the rate of the next fastest rate of increase $1 \approx .000060$, between latest Eocene and middle Miocene times; fig. 1). The extraordinarily rapid increase in ${ }^{87} \mathrm{Sr} /{ }^{86} \mathrm{Sr}$ with time across the PermoTriassic boundary may be an artifact of age assignment, since new ${ }^{39} \mathrm{Ar} /{ }^{40} \mathrm{Ar}$ dates show that some Permian boundary samples used for our fit are too young by several million years (R. Denison, pers. comm., 2000). Similarly, the curve from 480 to 500 is mostly constructed from samples from the Ar-

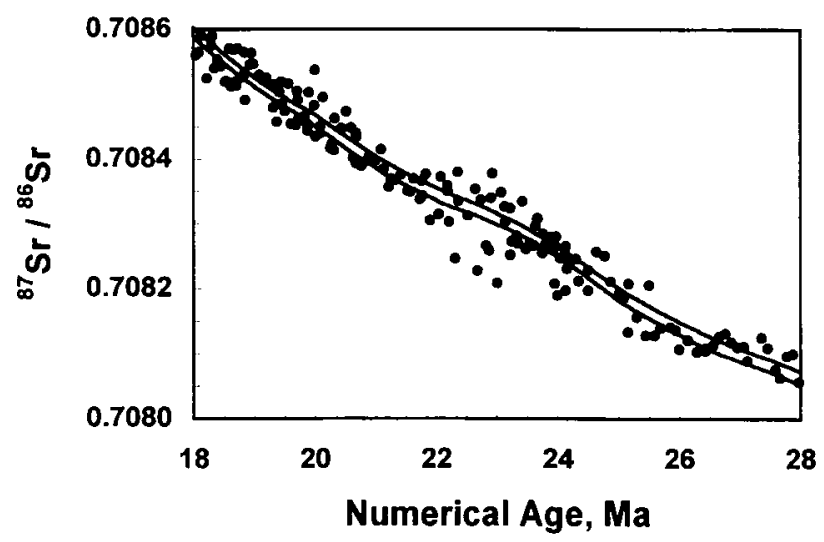

Figure 4. LOWESS data for the period 18-28 Ma. Time scale of Berggren et al. (1995). For clarity, only the upper and lower $95 \%$ confidence limits of the LOWESS fit are shown. 
buckle Limestone (Gao 1990), and assigning numerical ages to that unit proved difficult; the odd shape of the curve in this interval may indicate that the age model we have used is not adequate.

Finally, figure 1 reveals a paucity of data for many intervals of time (most of the Kimmeridgian and Berriasian, the late Albian to Coniacian, much of the Jurassic, the early Triassic, the Namurian and Westphalian, the lower Devonian, etc.). This lack of data is reflected in the large $(>0.000015)$ halfwidth of the confidence interval on the mean for the LOWESS fit (fig. 2a); to substantially reduce this uncertainty will require some 5-10 accurate and precise ${ }^{87} \mathrm{Sr} /{ }^{86} \mathrm{Sr}$ values per biozone.

\section{Uses for the Fit}

When assigning numerical ages to sediments or estimating the duration of a biozone or a hiatus in sedimentation, the task is made both easier and less prone to error by using the look-up table, which allows quick and easy conversion from ${ }^{87} \mathrm{Sr} /{ }^{86} \mathrm{Sr}$ to numerical age. For example, plots of ${ }^{87} \mathrm{Sr} /{ }^{86} \mathrm{Sr}$ with depth for ODP site 593 (fig. 5a) show two hiatuses, or condensed intervals, one flanked by samples at $393.5 \mathrm{mbsf}(0.708805,13.59 \pm 1.21 \mathrm{Ma})$ and 396.5 mbsf $(0.708722,16.44 \pm 0.44 \mathrm{Ma})$, the other by samples at $418.8 \mathrm{mbsf}(0.708598,17.98 \pm 0.26 \mathrm{Ma})$ and $420.8 \mathrm{mbsf}(0.708542,18.68 \pm 0.31 \mathrm{Ma})$. The durations of these events are $2.85 \pm 1.28 \mathrm{~m}$.yr. and $0.70 \pm 0.40$ m.yr., respectively. Similarly, in ODP site 590B (fig. 5b) a single hiatus, or condensed interval, is identified by the ${ }^{87} \mathrm{Sr} /{ }^{86} \mathrm{Sr}$ profile, between $463.6 \mathrm{mbsf}(0.708700,16.79 \pm 0.33 \mathrm{Ma})$ and 464.1 mbsf $(0.708593,18.04 \pm 0.25 \mathrm{Ma})$, which yields a duration of $1.25 \pm 0.41 \mathrm{~m}$.yr. for the event. In like manner, the hiatus in ODP site 926 (Martin et al. 1999) between 329.47 mbsf $(0.708760,15.64 \pm$ $0.84 \mathrm{Ma})$ and $333.95 \mathrm{mbsf}(0.708626,17.66 \pm 0.33$ $\mathrm{Ma})$ is $2.02 \pm 0.90 \mathrm{~m}$.yr. The hiatuses at sites 593 and 926 were identified only by $\mathrm{Sr}$ isotope analysis and not by biostratigraphy, which shows the value of ${ }^{87} \mathrm{Sr} /{ }^{86} \mathrm{Sr}$ profiling. In assigning errors, the uncertainties on numerical age given by the table are minimal values that take no formal account of uncertainties in the ages assigned to data used to generate the fit, since to assign uncertainties in numerical age to each datum in our database (3366 of them) would be both subjective and difficult. Nevertheless, where our data for any given time are drawn from more than one source, each with its own age model (mostly Neogene data), the LOWESS ages conflate age uncertainties that arise from the use of different sample sites and age models.

Many biostratigraphers prefer to work with bio-
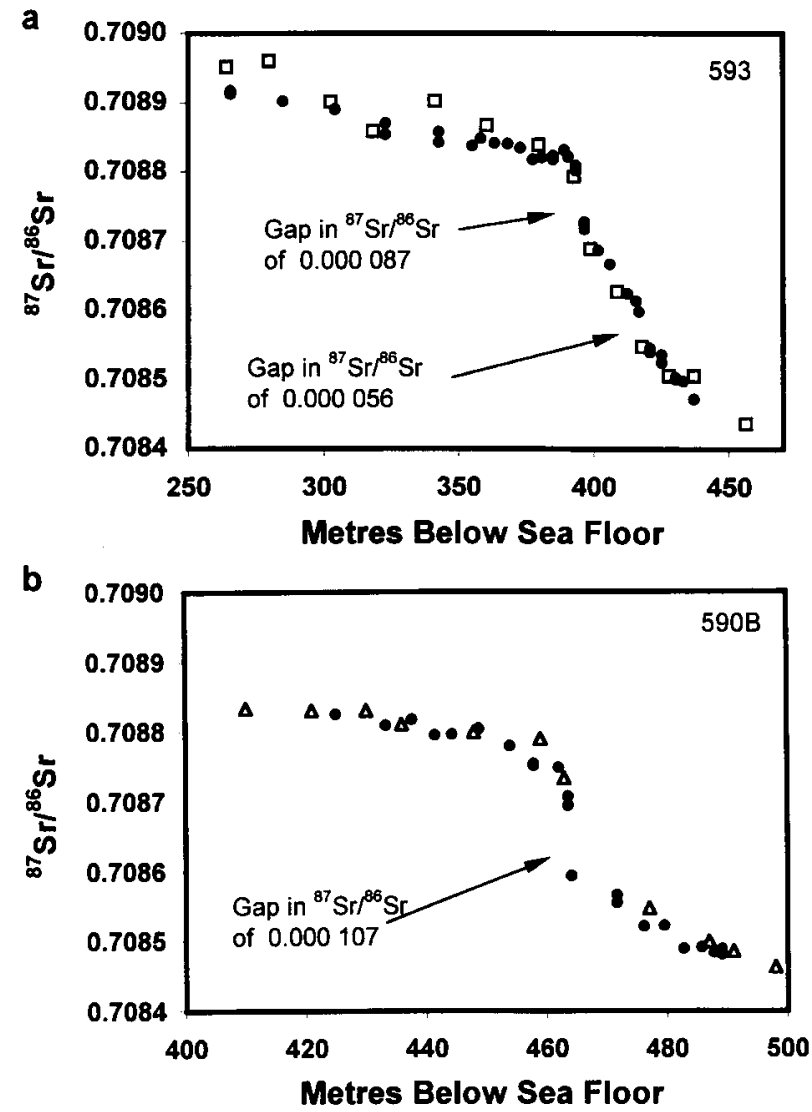

Figure 5. Depth profiles of ${ }^{87} \mathrm{Sr} /{ }^{86} \mathrm{Sr}$ in DSDP holes 593 $(a)$ and 590B (b). Filled black dots from J. M. McArthur, unpub. data; open squares from Hess et al. (1986); open triangles from DePaolo (1986). All data normalized to NIST 987 of 0.710248 . Gaps in the profile are discussed in the text.

stratigraphic, or magnetostratigraphic, ages rather than numerical ages. For them, our LOWESS fit is calibrated to accepted time scales. The table's numerical ages can be used simply as a transfer template to go from ${ }^{87} \mathrm{Sr} /{ }^{86} \mathrm{Sr}$ to biozonation or magnetochron. For example, for ODP site 590B, the bottom of the hiatus $(464.1 \mathrm{mbsf}$; fig. $5 b)$ has an ${ }^{87} \mathrm{Sr} /{ }^{86} \mathrm{Sr}$ of 0.708593 (18.04 m.yr. from the table). According to the time scale of Berggren et al. (1995), this equates to the lower part of Chron C5Dr, to the lowermost part of zone NN4 of the calcareous nannofossil zonation of Martini (1971), the middle of zone $\mathrm{N} 6$ of the planktonic foraminiferal zonation of Blow (1969), and so on.

The LOWESS fit also highlights some oddities in the shape of the marine ${ }^{87} \mathrm{Sr} /{ }^{86} \mathrm{Sr}$ curve for the lower Paleozoic, suggesting that the current ability to assign numerical ages to sediments has some shortcomings in this interval. For example, figure $1 g$ 
shows sharp inflections in the Giventian and the late Emsian. We believe that these inflections suggest inaccuracies in the time scale used both by ourselves (Young and Laurie 1996) and by Veizer et al. (1999; Harland et al. 1990) rather than truly representing the evolution of marine ${ }^{87} \mathrm{Sr} /{ }^{86} \mathrm{Sr}$ through those times. Our fit may suggest intervals for which age revisions are needed.

At a more detailed level, oddities can also be seen in the Jurassic part of the curve (figs. 6, 7). Figure 6 shows both data and the LOWESS fit for the Bajocian-Bathonian boundary interval. A ca. 3m.yr. plateau across the boundary is defined by the belemnite data of Jones et al. (1994a) and M. Engkilde (pers. comm., 1998). Furthermore, the Pliensbachian (Jurassic) data of Jones et al. (1994b) also show a plateau (fig. 7) of ca. 1 m.yr. within the Davoei zone of the Pliensbachian (lower Jurassic), defined by samples from localities that are $450 \mathrm{~km}$ apart (Yorkshire and Dorset coasts, United Kingdom) and have different lithologies. Jurassic ages were assigned by these authors largely by interpolating time between stage boundaries on the assumption that all zones (or subzones) within a stage are of equal duration (Gradstein et al. 1995). This procedure was used (since no better method for general use exists) even though it is probably wrong. Indeed, the duration of the ammonite zone in the late Pliensbachian and early Toarcian differed by a factor of between 4 (Pálfy and Smith 1998) and 30 (McArthur et al. 2000b).

Samples from oolitic, shallow-water limestones

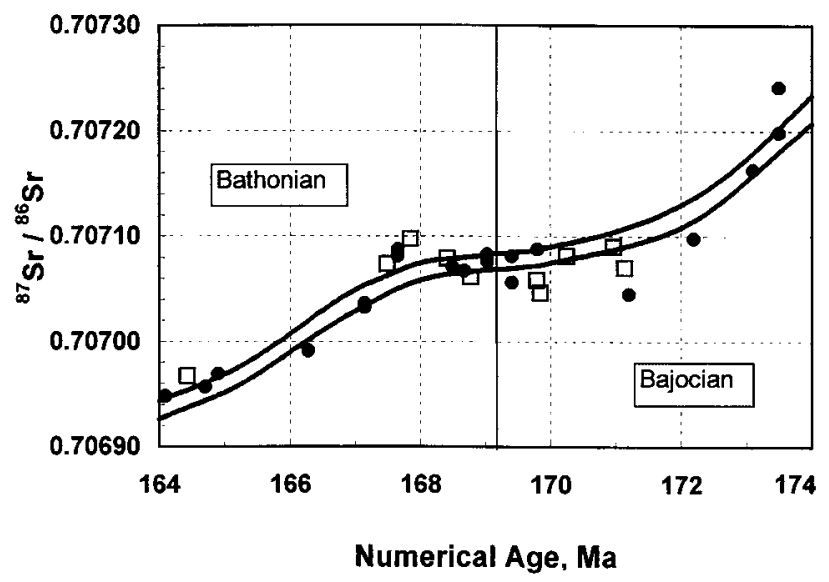

Figure 6. Plateau in ${ }^{87} \mathrm{Sr} /{ }^{86} \mathrm{Sr}$ across the Bajocian-Bathonian boundary in the data of Jones et al. (1994a; closed circles) and M. Engkilde (pers. comm. 1998; open squares). Time scale of Gradstein et al. (1995). Normalized to NIST 987 of 0.710248 . Lines are $95 \%$ upper and lower confidence limits on the LOWESS fit.

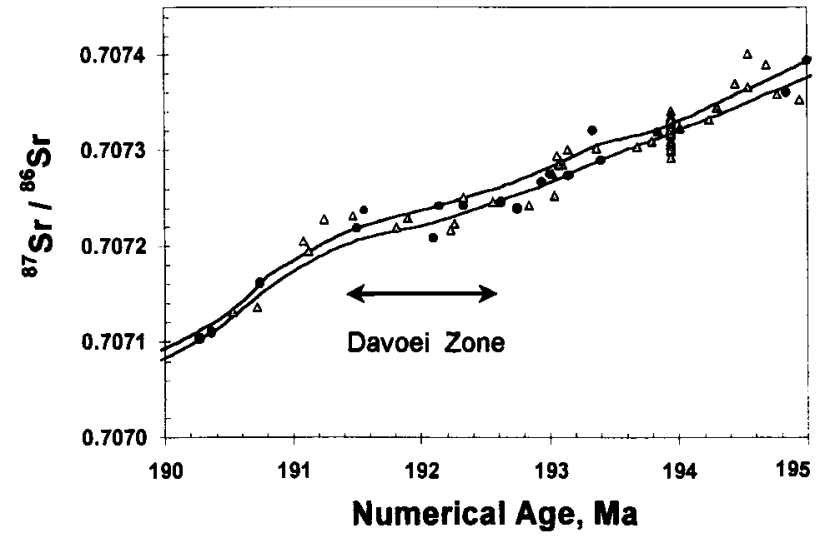

Figure 7. Plateau in ${ }^{87} \mathrm{Sr} /{ }^{86} \mathrm{Sr}$ from 191.8-192.6 Ma (Davoei zone) in data of Jones et al. (1994b). Time scale of Gradstein et al. (1995). Normalized to NIST 987 of 0.710248 . Lines are $95 \%$ upper and lower confidence limits on LOWESS fit.

(Great Oolite and Inferior Oolite) of the United Kingdom define the plateau across the BajocianBathonian boundary, while samples above and below the plateau were from other lithologies in the United Kingdom. We speculate that this plateau is an artifact of the fact that zone durations were shorter during deposition of boundary strata than at other times. Similarly, had the Davoei zone been much shorter in duration than adjacent zones, its plateau would shrink or disappear. We speculate that it was much shorter, since ammonite zones of the late Pliensbachian and early Toarcian differ in duration of up to a factor of 30 (McArthur et al. $2000 b$ ). A shortened Davoei zone is also consistent with the suggestion that ${ }^{87} \mathrm{Sr} /{ }^{86} \mathrm{Sr}$ changed linearly with time through the Pliensbachian (Weedon and Jenkyns 1999).

The LOWESS table was used by Poyato-Ariza et al. (1998) to provide a reference ${ }^{87} \mathrm{Sr} /{ }^{86} \mathrm{Sr}$ for marine $\mathrm{Sr}$ of late Barremian seawater and to show that late Barremian coelacanth and pycnodontiform fish from Cuenca, Spain, lived in a nonmarine environment in which ${ }^{87} \mathrm{Sr} /{ }^{86} \mathrm{Sr}(0.7076-0.7077)$ was well above the maximum ${ }^{87} \mathrm{Sr} /{ }^{86} \mathrm{Sr}$ of the Barremian ocean (0.707476 \pm 0.000011 from V3:10/99). Using the table, Taberner et al. (1999) dated evaporite minerals in the Eocene Ebro Basin as part of a reassessment of its filling history. Finally, the shape of our LOWESS curve can be used to underpin speculation about major geochemical cycles (cf. Kump 1989; Berner and Rye 1991; Godderis and Francois 1995; Derry and France-Lanord 1996). 


\section{Controls of the ${ }^{87} \mathrm{Sr} /{ }^{86} \mathrm{Sr}$ Trend}

The isotopic composition of marine ${ }^{87} \mathrm{Sr} /{ }^{86} \mathrm{Sr}$ is governed mostly by the flux from, and ${ }^{87} \mathrm{Sr} /{ }^{86} \mathrm{Sr}$ of, midocean ridge volcanism and continental weathering, but these four variables cannot be quantified through time with much certainty. Even the best known, the ${ }^{87} \mathrm{Sr} /{ }^{86} \mathrm{Sr}$ of mid-ocean ridge vent fluids, is imperfectly defined, even for today (when MORB approaches 0.7028 ), because of the uncertainty in quantifying the degree of $\mathrm{Sr}$ renewal (and so the ${ }^{87} \mathrm{Sr} /{ }^{86} \mathrm{Sr}$ ) in high-temperature MOR vent fluids (Bach and Humphris 1999). Such uncertainty is increased by ignorance of the flux of $\mathrm{Sr}$ in, and the ${ }^{87} \mathrm{Sr} /{ }^{86} \mathrm{Sr}$ of, fluids active in off-axis, low-temperature, hydrothermal systems. The ${ }^{87} \mathrm{Sr} /{ }^{86} \mathrm{Sr}$ of riverine $\mathrm{Sr}$ and its flux through time will depend on rock type and weathering rates and may be impossible to reconstruct. Despite these uncertainties, attempts have been made to explain and model the variation in marine ${ }^{87} \mathrm{Sr} /{ }^{86} \mathrm{Sr}$ through time, but without much success. Nevertheless, the trends in figure 1 must reflect geological events, and we need to establish the scale at which the ${ }^{87} \mathrm{Sr} /{ }^{86} \mathrm{Sr}$ record can be linked to them.

The largest changes of marine ${ }^{87} \mathrm{Sr} /{ }^{86} \mathrm{Sr}$ through time may be explicable. Although Precambrian data (Derry et al. 1989, 1992, 1994; Asmerom et al. 1991; Kaufman et al. 1993, 1996; Jabobsen and Kaufman 1999) are not in our LOWESS fit because of uncertainties over age assignment, these data (fig. 8a) show the trend in marine ${ }^{87} \mathrm{Sr} /{ }^{86} \mathrm{Sr}$ for enough of Precambrian time to define the Cambrian ${ }^{87} \mathrm{Sr} /{ }^{86} \mathrm{Sr}$ high. Values of ${ }^{87} \mathrm{Sr} /{ }^{86} \mathrm{Sr}$ increased from about 0.7055 at $800 \mathrm{Ma}$ to the Late Cambrian maximum of about 0.7091 at $500 \mathrm{Ma}$, before declining to the Oxfordian (0.7068 at $\approx 155 \mathrm{Ma})$. After the Oxfordian, ${ }^{87} \mathrm{Sr} /{ }^{86} \mathrm{Sr}$ increases, albeit through several reversals, to reach today's high of 0.709175. This trend has some parallels with the variation of sediment flux through Phanerozoic time (fig. $8 b$, as inferred by Floegel et al. 2000). Sediment flux peaked in early Paleozoic times and is nearly as high today, while the early to middle Mesozoic was a time not only of minimum sediment flux but also of minimum ${ }^{87} \mathrm{Sr} /{ }^{86} \mathrm{Sr}$ (fig. $8 a, 8 b$ ). This similarity supports the suggestion of Montañez et al. (2000, and references therein) that the marine ${ }^{87} \mathrm{Sr} /{ }^{86} \mathrm{Sr} \mathrm{rec}-$ ord primarily documents continental erosion and that the Cambrian ${ }^{87} \mathrm{Sr} /{ }^{86} \mathrm{Sr}$ high was the result of enhanced sediment and Sr flux (with high ${ }^{87} \mathrm{Sr} /{ }^{86} \mathrm{Sr}$ ) caused by uplift and weathering of metamorphic rocks formed during the Brasiliano-Pan African orogeny.

Interpretations of the shorter-term fluctuations
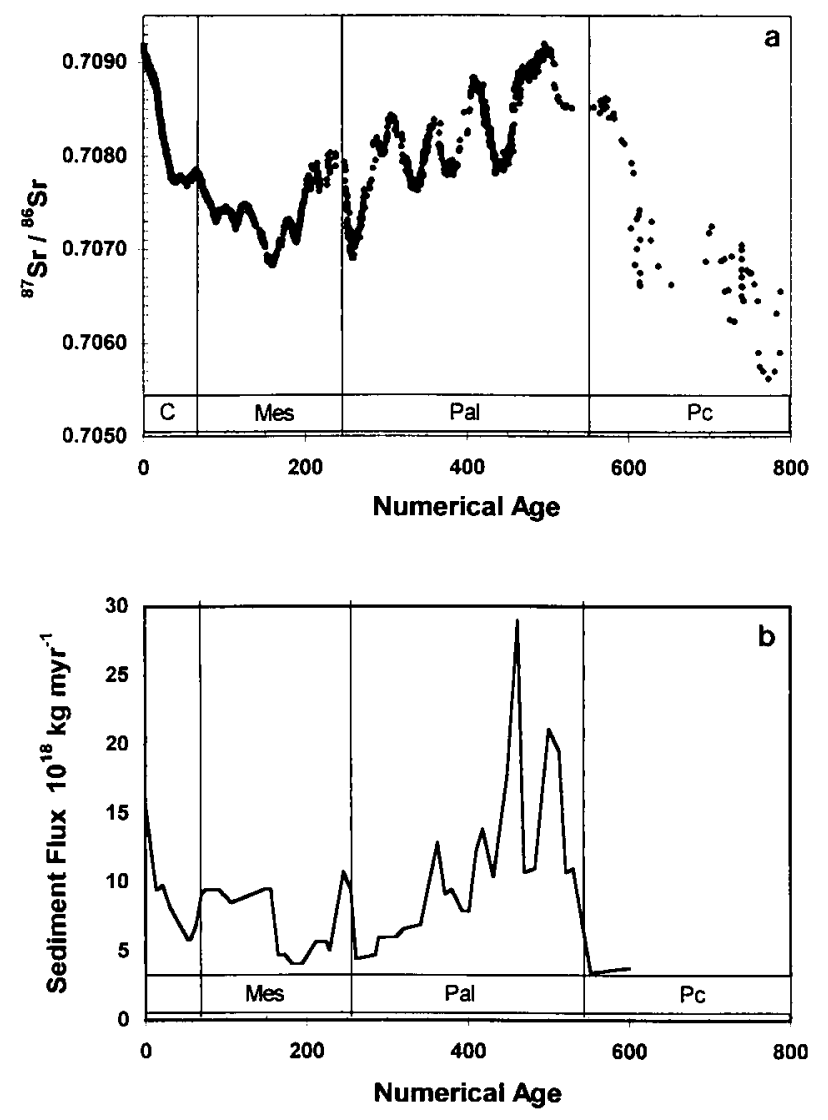

Figure 8. $a$, Trends in marine ${ }^{87} \mathrm{Sr} /{ }^{86} \mathrm{Sr}$ from $800 \mathrm{Ma}$ to today. Data from references in table 1 and Derry et al. (1989, 1992, 1994), Asmerom et al. (1991), Kaufman et al. (1993, 1996), and Jabobsen and Kaufman (1999). b, Sediment flux through time from Floegel et al. (2000).

attribute the steep Cenozoic increase, from 0.70773 at about $38 \mathrm{Ma}$ to 0.709175 today (fig. 4), to the consequences of enhanced weathering and/or unroofing of radiogenic rocks of the HimalayanTibetan uplift (Harris 1995 and many others before), to enhanced weathering associated with developing glaciation (Armstrong 1971; Miller et al. 1991; Zachos et al. 1999), or both operating together with decreased sea-floor volcanism (Mead and Hodell 1995). However, the ${ }^{87} \mathrm{Sr} /{ }^{86} \mathrm{Sr}$ of Himalayan rivers has changed greatly during Neogene times, and in a manner not reflected by changes in marine ${ }^{87} \mathrm{Sr} /{ }^{86} \mathrm{Sr}$ (Quade et al. 1997; Chesley et al. 2000). Furthermore, the increase in marine ${ }^{87} \mathrm{Sr} /{ }^{86} \mathrm{Sr}$, starting at about $38 \mathrm{Ma}$ and pronounced by $35 \mathrm{Ma}$ (fig. $(b)$, may have occurred before the major phase of Himalayan uplift in the Miocene (Harrison et al. 1992).

Zachos et al. (1999) link the Late Eoceneto-recent rise in ${ }^{87} \mathrm{Sr} /{ }^{86} \mathrm{Sr}$ with the development of 
ice sheets on Antarctica (temporary in the Late Eocene, permanent in the Oligocene; see also Armstrong 1971; Mead and Hodell 1995). The ${ }^{87} \mathrm{Sr} /{ }^{86} \mathrm{Sr}$ record for 35-38 $\mathrm{Ma}$ is probably not defined well enough to unequivocally support such an interpretation, but the possible link deserves further investigation. If the argument is correct, then an explanation emerges for the major break in slope of the marine ${ }^{87} \mathrm{Sr} /{ }^{86} \mathrm{Sr}$ record at about $15 \mathrm{Ma}$. This change of slope coincides with a major positive shift in the marine oxygen isotope record and with a major expansion of ice volume (Miller et al. 1987; Lear et al. 2000). If, as Zachos et al. (1999) imply (there is some uncertainty in age estimates), this ice expansion also coincided with a transition from wet-based ice sheets to cold, dry-based ice sheets and so to lessened (but still high) amounts of chemical weathering in Antarctica, the break in slope of the ${ }^{87} \mathrm{Sr} /{ }^{86} \mathrm{Sr}$ curve at $15 \mathrm{Ma}$ is, perhaps, explained.

In a wider context, however, explanations based on glaciation do not account for the fact that marine ${ }^{87} \mathrm{Sr} /{ }^{86} \mathrm{Sr}$ has been increasing steeply, with some reversals, since Oxfordian times. Thus, while Himalayan uplift and glaciation may contribute to rising oceanic ${ }^{87} \mathrm{Sr} /{ }^{86} \mathrm{Sr}$ during the Cenozoic, other underlying and stronger influences must be dominant.

We should also, perhaps, be seeking reasons why, between the K-T boundary and Late Eocene times, marine ${ }^{87} \mathrm{Sr} /{ }^{86} \mathrm{Sr}$ temporarily stopped increasing. The answer may lie in events related to Deccan Trap volcanism. There is some correspondence between the sharp inflections in the ${ }^{87} \mathrm{Sr} /{ }^{86} \mathrm{Sr}$ curve and the eruptions of major (mostly) continental flood basalts (CFBs) at 17, 65, 92, 110?, 125, 184?, 200?, 250, and $258 \mathrm{Ma}$ (Courtillot et al. 1996, 1999; fig. 9), although some inflections in the curve do not coincide with eruptions of CFBs (e.g., at 40, 45, 53,100 ?, 160, and $177 \mathrm{Ma}$ ) and several episodes of such volcanism $(30,60$, and $132 \mathrm{Ma})$ do not coincide with inflections in the curve. In view of the uncertainty of putting numerical ages on both $\mathrm{Sr}$ isotope data and flood basalt eruption (to say nothing of estimating the duration of eruptive flow), such conclusions are necessarily tentative. When better numerical ages can be established for some parts of the Sr isotope curve and for some episodes of flood basalt emplacement, events that fail to coincide may do so (and events that coincide now may no longer do so). Two such age revisions deserve mention: if the Triassic-Jurassic boundary, placed at 205.7 Ma in the time scale we use (Gradstein et al. 1995), is reduced to about $200 \mathrm{Ma}$, as seems warranted by new age constraints on the boundary (Pálfy et al. 1998), then the inflection at

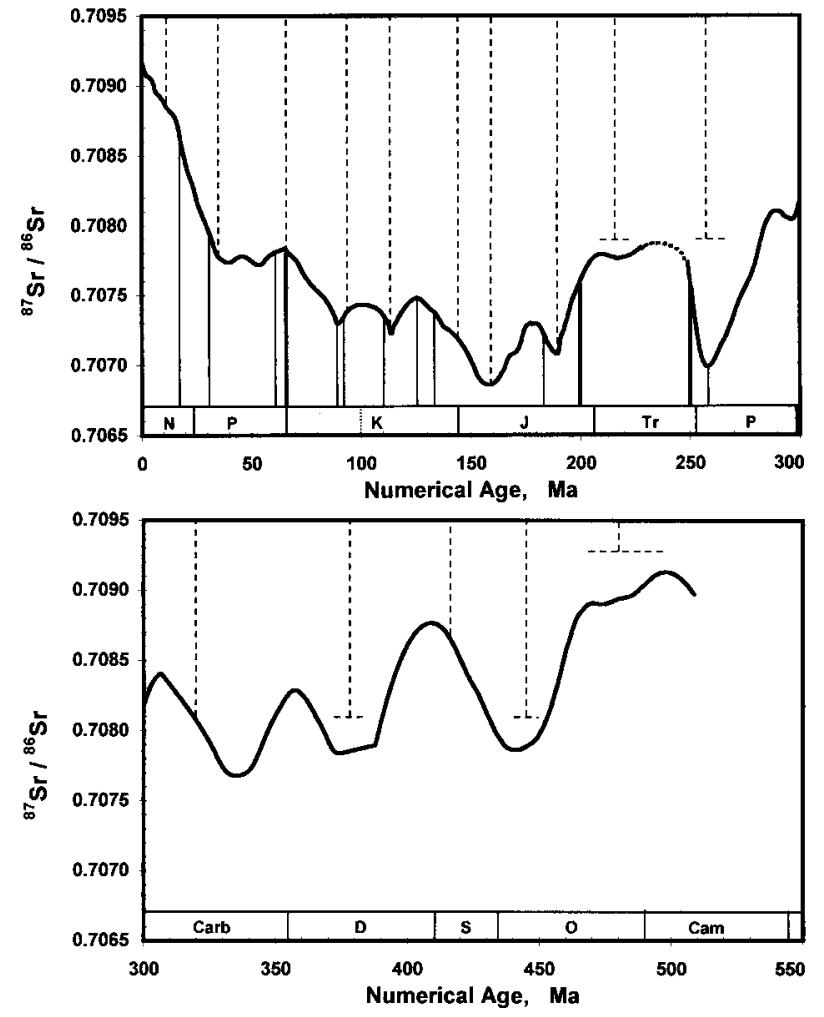

Figure 9. Relation to the marine ${ }^{87} \mathrm{Sr} /{ }^{86} \mathrm{Sr}$ record of times of severe volcanism and times of mass extinction. Volcanism represented by the eruption of continental flood basalts (CFBs), plus (submarine) Ontong Java Plateau and (mixed) Kerguelan Plateau, with times (mostly from Courtillot et al. 1996, 1999) marked as vertical solid lines with bolder lines for the three most voluminous CFBs. Mass extinction "events" (from Sepkoski 1993, 1994) are marked by vertical broken lines. Fitting artifacts in the early Triassic have been removed from the curve to show the probable real trend in the interval. Ages of CFBs in Ma: Columbia River, 17; EthiopianYemen, 30; Greenland, 60; Deccan, 65; Madagascar, 88; Kerguelen Plateau, 110; Otong Java Plateau, 125, 92 (Phinney et al. 1999); Parana-Etendeka, 132; KarooFarrar, 184; Central Atlantic Margin, 200 (Marzoli et al. 1999); Siberian, 250; Emeishan, 258.

the T-J boundary would coincide with the eruption of the Central Atlantic Margin flood basalts, dated at $200 \mathrm{Ma}$ (Courtillot et al. 1999; Marzoli et al. 1999; fig. 9a). Furthermore, if the numerical age of the Pliensbachian-Toarcian boundary, 189.6 in our compilation, were revised to about $184 \mathrm{Ma}$, as suggested by Pálfy et al. (1998), the minimum in the ${ }^{87} \mathrm{Sr} /{ }^{86} \mathrm{Sr}$ curve at the P-T boundary (fig. $1 d$; McArthur et al. 2000b) would coincide exactly with the time of $184 \mathrm{Ma}$ for the eruption of the KarooFarrar CFBs (Duncan et al. 1997; Courtillot et al. 
1999). On the present time scale, $184 \mathrm{Ma}$ corresponds to an inflection point in the late Toarcian part of the Sr curve, after which a poorly dated plateau possibly occupies much of late ToarcianAalenian time (fig. 1d). Finally, of the three largest CFB eruptions (Deccan, Siberia, Central Atlantic Margin), the two youngest (after adjusting to newest age determinations) mark abrupt downturns in the ${ }^{87} \mathrm{Sr} /{ }^{86} \mathrm{Sr}$ curve, at $65 \mathrm{Ma}$ and $201 \mathrm{Ma}$, and the third (250 Ma) appears to coincide with the arrest of the most dramatic rise in ${ }^{87} \mathrm{Sr} /{ }^{86} \mathrm{Sr}$ known, which was in the earliest Triassic (R. Denison, pers. comm., 2000) but is poorly dated.

Courtillot et al. (1996) present a case for a coincidence of flood-basalt eruption and mass extinction. There is also some correspondence between major extinctions and major inflections in the ${ }^{87} \mathrm{Sr} /{ }^{86} \mathrm{Sr}$ curve (fig. $9 \mathrm{~b}$ ). As the latter must reflect major geological, and probably climatological, upheavals in Earth history, the strength of the apparent coincidences needs to be examined. To do so properly is beyond the scope of this work, so we confine ourselves to two observations. First, some of the inflections in the ${ }^{87} \mathrm{Sr} /{ }^{86} \mathrm{Sr}$ curve are either poorly defined (end-Cenomanian, end-Triassic, Carboniferous) or poorly dated or both. Second, many extinction "events" were actually rather drawn-out affairs (Sepkoski 1993, 1994); the Permian extinctions, for example, while culminating in the Tatarian, were spread over the preceding two stages as well. When the ${ }^{87} \mathrm{Sr} /{ }^{86} \mathrm{Sr}$ record is better defined, the link between its shape and the extinction record and CFBs should be examined more closely.

\section{Conclusions}

Strontium isotope stratigraphy continues to evolve as a valuable tool to date and correlate marine sediments, but its power to do both is far from being fully realized. It is possible now to achieve a temporal and stratigraphic resolution close to an order of magnitude better than that commonly reported. Nevertheless, in some instances the method has, even now, provided better dating and correlation than has biostratigraphy or magnetostratigraphy. Analytical measurement is a bigger constraint on the method than is often realized, and we believe that once this issue has been fully addressed, the method will take its place alongside biostratigraphy, magnetostratigraphy, and direct dating (such as $\mathrm{Ar} / \mathrm{Ar}$ ) as one of the four essential tools of the stratigrapher. Given that measurement of an ${ }^{87} \mathrm{Sr} /{ }^{86} \mathrm{Sr}$ value to \pm 0.000003 is now possible, it is clear that a great deal of improvement needs to be made to most of the Phanerozoic ${ }^{87} \mathrm{Sr} /{ }^{86} \mathrm{Sr}$ curve if SIS is to realize its true potential for dating and correlating rocks.

\section{A C K N O W L E D G M E N T S}

We thank M. F. Thirlwall, director of the Radiogenic Isotope Laboratory at Royal Holloway University of London, for use of the laboratory over an extended period; M. Engkilde for the use of unpublished data; and $\mathrm{N}$. Janssen for providing samples. We thank B. Runnegar, G. Shields, and an anonymous referee for constructive reviews of the manuscript.

\section{R E F E R E N C E S C I T E D}

Armstrong, R. L. 1971. Glacial erosion and the variable isotopic composition of strontium in seawater. Nature 230:132-134.

Asmerom, Y.; Jacobsen, S. B.; Knoll, A. H.; Butterfield, N. J.; and Swett, K. 1991. Strontium isotopic variations of Neoproterozoic seawater: implication for crustal evolution. Geochim. Cosmochim. Acta 55: 2883-2894.

Bach, W., and Humphris, S. E. 1999. Relationship between the $\mathrm{Sr}$ and $\mathrm{O}$ isotope compositions of hydrothermal fluids and the spreading and magma-supply rates at oceanic spreading centers. Geology 27:1067-1070.

Bailey, T. R.; McArthur, J. M.; Prince, H.; and Thirlwall, M. F. 2000. Dissolution methods for strontium isotope stratigraphy: whole rock analysis. Chem. Geol. 167: 313-319.

Banner, J. L., and Kaufman, J. 1994. The isotopic record of ocean chemistry and diagenesis preserved in nonluminescent brachiopods from Mississippian carbonate rocks, Illinois and Missouri. Geol. Soc. Am. Bull. 106:1074-1082.

Beets, C. J. 1992. Calibration of late Cenozoic marine strontium isotope variations and its chronostratigraphic and geochemical applications. Ph.D. thesis, Free University, Amsterdam.

Berggren, W. A.; Kent, D. V.; Swisher, C. C.; and Aubry, M.-P. 1995. A revised Cenozoic geochronology and chronostratigraphy. In Geochronology, time scales and global stratigraphic correlation. SEPM Spec. Publ. 54:129-212. Tulsa, Okla., Society for Sedimentary Geology.

Berner, R. A., and Rye, D. M. 1991. Calculation of the Phanerozoic strontium isotope record of the oceans from a carbon cycle model. Am. J. Sci. 292:136-148. 
Bertram, C. J.; Elderfield, H.; Aldridge, R. J.; and Conway Morris, S. $1992 .{ }^{87} \mathrm{Sr} /{ }^{86} \mathrm{Sr},{ }^{143} \mathrm{Nd} /{ }^{144} \mathrm{Nd}$, and REEs in Silurian phosphatic fossils. Earth Planet. Sci. Lett. 113: 239-249.

Blow, W. H. 1969. Late Middle Eocene to recent planktonic foraminiferal biostratigraphy. In Bronnimann, P., and Renz, H. H., eds. Proceedings of the First International Conference on Planktonic Microfossils (Geneva, 1967). Leiden, E. J. Brill, 1:199-421.

Bralower, T. J.; Fullagar, P. D.; Paull, C. K.; Dwyer, G. S.; and Leckie, R. M. 1997. Mid-Cretaceous strontiumisotope stratigraphy of deep-sea sections. Geol. Soc. Am. Bull. 109:1421-1442.

Bruckschen, P.; Bruhn, F.; Veizer, J.; and Buhl, D. 1995. ${ }^{87} \mathrm{Sr} /{ }^{86} \mathrm{Sr}$ isotopic evolution of lower Carboniferous seawater: dinantian of western Europe. Sediment. Geol. 100:63-81.

Callomon, J. 2000. On the proposed basal boundary stratotype (GSSP) of the Middle Jurassic Callovian Stage. GeoRes. Forum 6:41-54.

Cande, S. C., and Kent, D. V. 1995. Revised calibration of the geomagnetic polarity timescale for the Late Cretaceous and Cenozoic. J. Geophys. Res. 100: 6093-6095.

Carpenter, S. J.; Lohmann, K. C.; Holden, P.; Walter, L. M.; Huston, T. J.; and Halliday, A. N. 1991. $\delta^{18} \mathrm{O}$ values, ${ }^{87} \mathrm{Sr} /{ }^{86} \mathrm{Sr}$ and $\mathrm{Sr} / \mathrm{Mg}$ ratios of Late Devonian abiotic calcite: implications for the composition of ancient seawater. Geochim. Cosmochim. Acta 55: 1991-2010.

Chambers, J. M.; Cleveland, W. S.; Kleiner, B.; and Tukey, P. A. 1983. Graphical methods for data analysis. Belmont, Calif., Wadsworth, 395 pp.

Chesley, J. T.; Quade, J.; and Ruiz, J. 2000. The Os and $\mathrm{Sr}$ isotopic record of Himalayan paleorivers: Himalayan tectonics and influence on ocean chemistry. Earth Planet. Sci. Lett. 179:115-124.

Clemens, S. C.; Farrell, J. W.; and Gromet, L. P. 1993. Synchronous changes in seawater strontium isotope composition and global climate. Nature 363:607-610.

Clemens, S. C.; Gromet, L. P.; and Farrell, J. W. 1995. Artifacts in Sr isotope records. Nature 373:201.

Cleveland, W. S. 1979. Robust locally weighted regression and smoothing scatterplots. J. Am. Stat. Assoc. 74:829-836.

Cleveland, W. S.; Grosse, E.; and Shyu, W. M. 1992. Local regression models. In Chambers, J. M., and Hastie, T., eds. Statistical models in S. Pacific Grove, Calif., Wadsworth \& Brooks/Cole, p. 309-376.

Courtillot, V.; Jaeger, J.-J.; Yang, Z.; Féraud, G.; and Hofmann, C. 1996. The influence of continental flood basalts on mass extinctions: where do we stand? In Ryder, G.; Fastovsky, D.; and Gartner, S., eds. The Cretaceous-Tertiary event and other catastrophes in earth history. Boulder, Colo., Geol. Soc. Am., Spec. Pap. 307.

Courtillot, V.; Jaupart, C.; Manighetti, I.; Tapponnier, P.; and Besse, J. 1999. On causal links between flood basalts and continental breakup. Earth Planet. Sci. Lett. 166:177-195.
Crame, A. J.; McArthur, J. M.; Pirrie, D.; and Riding, J. B. 1999. Strontium isotope correlation of the basal Maastrichtian stage in Antarctica to the European and U.S. standard biostratigraphic schemes. J. Geol. Soc. Lond. 156:957-964.

Cummins, D. I., and Elderfield, H. 1994. The strontium isotopic composition of Brigantian (late Dinantian) seawater. Chem. Geol. 118:255-270.

Denison, R. E.; Koepnick, R. B.; Burke, W. H.; and Hetherington, E. A. 1998. Construction of the Cambrian and Ordovician seawater ${ }^{87} \mathrm{Sr} /{ }^{86} \mathrm{Sr}$ curve. Chem. Geol. 152:325-340.

Denison, R. E.; Koepnick, R. B.; Burke, W. H.; Hetherington, E. A.; and Fletcher, A. 1994. Construction of the Mississippian, Pennsylvanian and Permian seawater ${ }^{87} \mathrm{Sr} /{ }^{86} \mathrm{Sr}$ curve. Chem. Geol. 112:145-167.

- 1997. Construction of the Silurian and Devonian seawater ${ }^{87} \mathrm{Sr} /{ }^{86} \mathrm{Sr}$ curve. Chem. Geol. 140:109-121.

Denison, R. E.; Koepnick, R. B.; Fletcher, A.; Dahl, D. A.; and Baker, M. C. 1993. Re-evaluation of Early Oligocene, Eocene, and Paleocene seawater ${ }^{87} \mathrm{Sr} /{ }^{86} \mathrm{Sr}$ using outcrop samples from the U.S. Gulf Coast. Paleoceanography 8:101-126.

DePaolo, D. J. 1986. Detailed record of the Neogene Sr isotopic evolution of seawater from DSDP site 590B. Geology 14:103-106.

DePaolo, D. J., and Ingram, B. 1985. High-resolution stratigraphy with strontium isotopes. Science 227: 938-941.

Derry, L. A.; Brasier, M. D.; Corfield, R. M.; Rozanov, A. Y.; and Zhuravlev, A. Y. 1994. Sr and C isotopes in lower Cambrian carbonates from the Siberian craton: a paleoenvironmental record during the "Cambrian" explosion. Earth Planet. Sci. Lett. 128:671-681.

Derry, L. A., and France-Lanord, C. 1996. Neogene Himalayan weathering history and river ${ }^{87} \mathrm{Sr} /{ }^{86} \mathrm{Sr}$ : impact on the marine Sr record. Earth Planet. Sci. Lett. 142: 59-74.

Derry, L. A.; Kaufman, A. J.; and Jacobsen, S. B. 1992. Sedimentary cycling and environmental change in the late Proterozoic: evidence from stable and radiogenic isotopes. Geochim. Cosmochim. Acta 56:1317-1329.

Derry, L. A.; Keto, L. S.; Jacobsen, S. B.; Knoll, A. H.; and Swett, K. 1989. Sr isotopic variations in upper Proterozoic carbonates from Svalbard and East Greenland. Geochim. Cosmochim. Acta 53:2331-2339.

Diener, A.; Ebneth, S.; Veizer, J.; and Buhl, D. 1996. Strontium isotope stratigraphy of the Middle Devonian: brachiopods and conodonts. Geochim. Cosmochim. Acta 60:639-652.

Dingle, R. V., and Lavelle, M. 1998. Late Cretaceous-Cenozoic climatic variations of the northern Antarctic Peninsula: new geochemical evidence and review. Palaeogeogr. Palaeoclimatol. Palaeoecol. 141: 215-232.

Dingle, R. V.; McArthur, J. M.; and Vroon, P. 1997. Oligocene and Pliocene interglacial events in the Antarctic Peninsula dated using strontium isotope stratigraphy. J. Geol. Soc. Lond. 154:257-264.

Duncan, R. A.; Hooper, P. R.; Rehacek, J.; Marsh J. S.; 
and Duncan, A. R. 1997. The timing and duration of the Karoo igneous event, Southern Gondwana. J. Geophys. Res. 102:18,127-18,138.

Farrell, J. W.; Clemens, S. C.; and Gromet, L. P. 1995. Improved chronostratigraphic reference curve of late Neogene seawater ${ }^{87} \mathrm{Sr} /{ }^{86} \mathrm{Sr}$. Geology 23:403-406.

Floegel, S.; Wold, C. N.; and Hay, W. W. 2000. Evolution of sediments and ocean salinity. 31st Int. Geol. Congr., Rio de Janeiro, Brazil, August 2000, abstract.

Gale, A. S.; Montgomery, P.; Kennedy, W. J.; Hancock, W. M.; Burnett, J. A.; and McArthur, J. M. 1995. Definition and global correlation of the Santonian-Campanian boundary. Terra Nova 7:611-622.

Gao, G. 1990. Geochemical and isotopic constraints on the diagenetic history of a massive stratal, late Cambrian (Royer) dolomite, Lower Arbuckle Group, Slick Hills, SW Oklahoma, USA. Geochim. Cosmochim. Acta 54:1979-1989.

Godderis, Y., and Francois, L. M. 1995. The Cenozoic evolution of the strontium and carbon cycles: relative importance of continental erosion and mantle exchanges. Chem. Geol. 126:169-190.

Gradstein, F. M.; Agterberg, F. P.; Ogg, J. G.; Hardenbol, J.; Van Veen, P.; and Huang, Z. 1995. A Mesozoic time scale. J. Geophys. Res. 99(B12):24,051-24,074.

Harland, W. B.; Armstrong, R. L.; Cox, A. V.; Craig, L. E.; Smith, A. G.; and Smith, D. G. 1990. A geologic time scale 1989. Cambridge, Cambridge University Press, 263 pp.

Harris, N. 1995. Significance of weathering Himalayan metasedimentary rocks and leucogranites for the $\mathrm{Sr}$ isotope evolution of seawater during the early Miocene. Geology 23:795-798.

Harrison, T. M.; Copeland, P.; Kidd, W. S. F.; and Yin, A. 1992. Raising Tibet. Science 255:1663-1670.

Henderson, G. M.; Martel, D. J.; O'Nions, R. K.; and Shackleton, N. J. 1994. Evolution of seawater ${ }^{87} \mathrm{Sr} /{ }^{86} \mathrm{Sr}$ over the last $400 \mathrm{ka}$ : the absence of glacial/interglacial cycles. Earth Planet. Sci. Lett. 128:643-651.

Hess, J.; Bender, M. L.; and Schilling, J.-G. 1986. Evolution of the ratio of strontium-87 to strontium-86 in seawater from Cretaceous to present. Science 231: 979-984.

Hess, J.; Stott, L. D.; Bender, M. L.; Kennet, J. P.; and Schilling, J.-G. 1989. The Oligocene marine microfossil record: age assessments using strontium isotopes. Paleoceanography 4:655-679.

Hodell, D. A.; Mead, G. A.; and Mueller, P. A. 1990. Variation in the strontium isotopic composition of seawater (8 $\mathrm{Ma}$ to present): implications for chemical weathering rates and dissolved fluxes to the oceans. Chem. Geol. (Isot. Geosci. Sect.) 80:291-307.

Hodell, D. A.; Mueller, P. A.; and Garrido, J. R. 1991. Variations in the strontium isotopic composition of seawater during the Neogene. Geology 19:24-27.

Hodell, D. A.; Mueller, P. A.; McKenzie, J. A.; and Mead, G. A. 1989. Strontium isotope stratigraphy and geochemistry of the late Neogene ocean. Earth Planet. Sci. Lett. 92:165-178.

Hodell, D. A., and Woodruff, F. 1994. Variations in the
${ }^{87} \mathrm{Sr} /{ }^{86} \mathrm{Sr}$ of seawater during the Miocene: stratigraphic and geochemical implications. Paleoceanography 9: 405-426.

Howarth, R. J., and McArthur, J. M. 1997. Statistics for strontium isotope stratigraphy: a robust LOWESS fit to the marine strontium isotope curve for the period 0 to $206 \mathrm{Ma}$, with look-up table for the derivation of numerical age. J. Geol. 105:441-456.

Jacobsen, S. B., and Kaufman, A. J. 1999. The Sr, C and $\mathrm{O}$ isotopic evolution of Neoproterozoic seawater. Chem. Geol. 161:37-57.

Jenkyns, H. C.; Paull, K.; Cummins, D. I.; and Fullagar, P. D. 1995. Strontium-isotope stratigraphy of lower Cretaceous atoll carbonates in the mid Pacific Mountains. Proc. Ocean Drilling Prog. Sci. Results 143: 89-97.

Jones, C. E.; Jenkyns, H. C.; Coe, A. L.; and Hesselbo, S. P. $1994 a$. Strontium isotope variations in Jurassic and Cretaceous seawater. Geochim. Cosmochim. Acta 58:3061-3074.

Jones, C. E.; Jenkyns, H. C.; and Hesselbo, S. P. $1994 b$. Strontium isotopes in Early Jurassic seawater. Geochim. Cosmochim. Acta 58:1285-1301.

Kaufman, A. J.; Jacobsen, S. B.; and Knoll, A. H. 1993. The Vendian record of $\mathrm{Sr}$ and $\mathrm{C}$ isotopic variations in seawater: implications for tectonics and paleoclimate. Earth Planet. Sci. Lett. 120:409-430.

Kaufman, A. J.; Knoll, A. H.; Semikhatov, M. A.; Grotzinger, J. P.; Jacobsen, S. B.; and Adams, W. 1996. Integrated chronostratigraphy of Proterozoic-Cambrian boundary beds in the western Anabar region, northern Siberia. Geol. Mag. 133:509-533.

Koepnick, R. B.; Denison, R. E.; Burke, W. H.; Hetherington, E. A.; and Dahl, D. A. 1990. Construction of the Triassic and Jurassic portion of the Phanerozoic curve of seawater ${ }^{87} \mathrm{Sr} /{ }^{86} \mathrm{Sr}$. Chem. Geol. (Isot. Geosci. Sect.) 80:327-349.

Kump, L. R. 1989. Alternative modeling approaches to the geochemical cycles of carbon, sulfur, and strontium isotopes. Am. J. Sci. 289:390-410.

Lear, C. H.; Elderfield, H.; and Wilson, P. 2000. Cenozoic deep-sea temperature and global ice volumes from $\mathrm{Mg} / \mathrm{Ca}$ in benthic foraminiferal calcite. Science 287: 269-272.

Martin, E. E., and Macdougall, J. D. 1995. Sr and Nd isotopes at the Permian/Triassic boundary: a record of climate change. Chem. Geol. 125:73-99.

Martin, E. E.; Shackleton, N. J.; Zachos, J. C.; and Flower, B. P. 1999. Orbitally-tuned Sr isotope chemostratigraphy for the late middle to late Miocene. Paleoceanography 14:74-83.

Martini, E. 1971. Standard Tertiary and Quaternary calcareous nannoplankton zonation. In Farinacci, A., ed. Proceedings of the Second Planktonic Conference (Rome, 1970). Tecnoscienza, p. 739-785.

Marzoli, A.; Renne, P. R.; Piccirillo, E. M.; Ernesto, M.; Bellieni, G.; and DeMin, A. 1999. Extensive 200-million-year-old continental flood basalts of the Central Atlantic Magmatic Province. Science 284:616-618. 
McArthur, J. M. 1994. Recent trends in strontium isotope stratigraphy. Terra Nova 6:331-358.

McArthur, J. M.; Chen, M.; Gale, A. S.; Thirlwall, M. F.; and Kennedy, W. J. 1993a. Strontium isotope stratigraphy for the Late Cretaceous: age models and intercontinental correlations for the Campanian. Paleoceanography 8:859-873.

McArthur, J. M.; Crame, A. J.; and Thirlwall, M. F. $2000 a$. Major revision of Late Cretaceous stratigraphy of Antarctica using strontium isotope stratigraphy. J. Geol. 108:623-640.

McArthur, J. M.; Donovan, D. T.; Thirlwall, M. F.; Fouke, B. W.; and Mattey, D. 2000b. Strontium isotope profile of the early Toarcian (Jurassic) Oceanic Anoxic Event, the duration of ammonite biozones, and belemnite paleotemperatures. Earth Planet. Sci. Lett. 179: 269-285.

McArthur, J. M., and Howarth, R. J. 1998. Strontium isotope stratigraphy: LOWESS V2. A revised best-fit to the marine Sr-isotope curve for 0 to $206 \mathrm{Ma}$, with a revised look-up table for derivation of numeric age. Am. Assoc. of Petrol. Geologists Annual Meeting (Salt Lake City, Utah, May 17-20, 1988), Tulsa, Okla., AAPG.

McArthur, J. M.; Kennedy, W. J.; Chen, M.; Thirlwall, M. F.; and Gale, A. S. 1994. Strontium isotope stratigraphy for the Late Cretaceous: direct numerical age calibration of the Sr-isotope curve for the U.S. Western Interior Seaway. Palaeogeogr. Palaeoclimatol. Palaeoecol. 108:95-119.

McArthur, J. M.; Kennedy, W. J.; Gale, A. S.; Thirlwall, M. F.; Chen, M.; Burnett, J.; and Hancock, J. M. 1992. Strontium-isotope stratigraphy in the Late Cretaceous. intercontinental correlation of the Campanian/ Maastrichtian boundary. Terra Nova 4:385-393.

McArthur, J. M., and Morton, M. 2000. Strontium isotope stratigraphy of the Aalenian/Bajocian auxiliary stratotype point at Bearreraig, Isle of Skye, NW Scotland. GeoRes. Forum 6:137-144.

McArthur, J. M.; Thirlwall, M. F.; Burnett, J.; Kennedy, W. J.; Gale, A. S.; Mattey, D.; and Lord, A. R. 1993 b. Strontium-isotope stratigraphy in the Late Cretaceous: a new curve, based on the English Chalk. In Hailwood, E., and Kid, R., eds. High resolution stratigraphy. Geol. Soc. Lond. Spec. Publ. 70:195-209.

McArthur, J. M.; Thirlwall, M. F.; Engkilde, M.; Zinsmeister, W. J.; and Howarth, R. J. 1998. Strontium isotope profiles across $\mathrm{K} / \mathrm{T}$ boundary sequences in Denmark and Antarctica. Earth Planet. Sci. Lett. 160: 179-192.

Mc Laughlin, Ò. M.; McArthur, J. M.; Thirlwall, M. F.; Gale, A. S.; Burnett, J.; and Kennedy, W. J. 1995. Sr isotope evolution of Maastrichtian seawater determined from the Chalk of Hemmoor, NW Germany. Terra Nova 7:491-499.

Mead, G. A., and Hodell, D. A. 1995. Controls on the ${ }^{87} \mathrm{Sr} /{ }^{86} \mathrm{Sr}$ composition of seawater from middle Eocene to Oligocene: hole 689B, Maud Rise, Antarctica. Paleoceanography 10:327-346.

Miller, K. G.; Fairbanks, R. G.; and Mountain, G. S. 1987.
Tertiary oxygen isotope synthesis, sea level history, and continental margin erosion. Paleoceanography 2: $1-19$.

Miller, K. G.; Feigenson, M. D.; Kent, D. V.; and Olson, R. K. 1988. Upper Eocene to Oligocene isotope $\left({ }^{87} \mathrm{Sr} /{ }^{86} \mathrm{Sr}, \delta 18 \mathrm{O}, \delta 13 \mathrm{C}\right)$ standard section, Deep Sea Drilling Project site 522. Paleoceanography 3:223-233.

Miller, K. G.; Feigenson, M. D.; Wright, J. D.; and Clement, B. M. 1991. Miocene isotope reference section, Deep Sea Drilling Project site 608: an evaluation of isotope and biostratigraphic resolution. Paleoceanography $6: 33-52$.

Montanari, A.; Deino, A.; Coccioni, R.; Langenheim, V. E.; Capo, R.; and Monechi, S. 1991. Sr isotope analysis, magnetostratigraphy and plankton stratigraphy across the Oligocene-Miocene boundary in the Contessa section (Gubbio, Italy). Newsl. Stratigr. 23: 151-180.

Montañez, I. P.; Banner, J. L.; Osleger, D. A.; Borg, L. E.; and Bosserman, P. J. 1996. Integrated Sr isotope variations and sea level history of middle to upper Cambrian platform carbonates: implications for the evolution of Cambrian seawater ${ }^{87} \mathrm{Sr} /{ }^{86} \mathrm{Sr}$. Geology 24: 917-920.

Montañez, I. P.; Osleger, D. A.; Banner, J. L.; Mack, L. E.; and Musgrove, M. 2000. Evolution of the Sr and C isotope composition of Cambrian oceans. GSA Today 10:1-7.

Obradovich, J. D. 1993. A Cretaceous timescale in evolution of the Western Interior Foreland Basin. In Caldwell, W. G. E., ed. Geol. Assoc. Can. Spec. Pap. 39: 379-396.

Oslick, J. S.; Miller, K. G.; Feigenson, M. D.; and Wright, J. D. 1994. Oligocene-Miocene strontium isotopes: stratigraphic revisions and correlations to an inferred glacioeustatic record. Paleoceanography 9:427-443.

Pálfy, J., and Smith, P. L. 1998. Timing of Early Jurassic recoveries and spacing of mass extinctions. Proceedings of the International Symposium on Jurassic Stratigraphy (Vancouver, September 1998), Switzerland, Trans Tech.

Pálfy, J.; Smith, P. L.; and Mortensen, J. K. 1998. A revised numeric time scale for the Jurassic. Proceedings of the International Symposium on Jurassic Stratigraphy (Vancouver, September 1998), Switzerland, Trans Tech.

Phinney, E. J.; Mann, P.; Coffin, M. F.; and Shipley, T. H. 1999. Sequence stratigraphy, structure, and tectonic history of the southwestern Ontong Java Plateau adjacent to the North Solomon trench and Solomon Islands arc. J. Geophys. Res. 104:20,449-20,466.

Poyato-Ariza, F. J.; Talbot, M. R.; Fregenal-Martinez, M. A.; Melendez, N.; and Wenz, S. 1998. First isotopic and multidisciplinary evidence for non-marine coelacanths and pycnodontiform fishes: paleoenvironmental implications. Palaeogeogr. Palaeoclimatol. Palaeoecol. 144:65-84.

Qing, H.; Barnes, C. R.; Buhl, D.; and Veizer, J. 1998. The strontium isotopic composition of Ordovician and Silurian brachiopods and conodonts: relationships to 
geological events and implications for coeval seawater. Geochim. Cosmochim. Acta 62:1721-1723.

Quade, J.; Roe, L.; DeCelles, P. G.; and Ojha, T. P. 1997. The late Neogene Sr-87/Sr-86 record of lowland Himalayan rivers. Science 276:1828-1831.

Reinhardt, E. G.; Cavazza, W.; Patterson, R. T.; and Blenkinsop, J. 2000. Differential diagenesis of sedimentary components and the implication for strontium isotope analysis of carbonate rocks. Chem. Geol. 164: 331-343.

Ruppel, S. C.; James, E. W.; Barrick, J. E.; Nowlan, G.; and Uyeno, T. T. 1996. High-resolution ${ }^{87} \mathrm{Sr} /{ }^{86} \mathrm{Sr}$ chemostratigraphy of the Silurian: implications for event correlation and strontium flux. Geology 24:831-834.

Schmitz, B.; Aberg, G.; Werdelin, L.; Forey, P.; and Bendix-Almgreen, S. E. $1991 .{ }^{87} \mathrm{Sr} /{ }^{86} \mathrm{Sr}, \mathrm{Na}, \mathrm{F}, \mathrm{Sr}$ and $\mathrm{La}$ in skeletal fish debris as a measure of the paleosalinity of fossil-fish habitats. Geol. Soc. Am. Bull. 103: 786-794.

Sepkoski, J. J. 1993. 10 years in the library: new data confirm paleontological patterns. Paleobiology 19: 43-51.

- 1994. Extinction and the fossil record. Geotimes 39:15-17.

Shackleton, N. J.; Crowhurst, S.; Hagelberg, T.; Pisias, N. G.; and Schneider, D. A. 1995. A new late Neogene time scale: application to Leg 138 sites. In Pisias, N. G.; Mayer, L. A.; Janecek, T. R.; Palmer-Julsen, A.; and van Andel, T. H., eds. Proc. Ocean Drilling Program Sci. Results 138:73-101.

Sugarman, P. J.; Miller, K. G.; Bukry, D.; and Feigenson, M. D. 1995. Uppermost Campanian-Maastrichtian strontium isotopic, biostratigraphic, and sequence stratigraphic framework of the New Jersey coastal plain. Geol. Soc. Am. Bull. 107:19-37.
Taberner C.; Dinarès-Turell, J.; Giménez, J.; and Docherty, C. 1999. Basin infill architecture and evolution from magnetostratigraphic cross-basin correlations in the southern Pyrenean foreland basin. Geol. Soc. Am. Bull. 111:1155-1174.

Thisted, R. A. 1988. Elements of statistical computing. New York, Chapman \& Hall, 427 pp.

Veizer, J.; Ala, D.; Azmy, K.; Bruckschen, P.; Buhl, D.; Bruhn, F.; Carden, G. A. F., et al. 1999. ${ }^{87} \mathrm{Sr} /{ }^{86} \mathrm{Sr}, \delta^{13} \mathrm{C}$ and $\delta^{18} \mathrm{O}$ evolution of Phanerozoic seawater. Chem. Geol. 161:59-88.

Veizer, J.; Buhl, D.; Diener, A.; Ebneth, S.; Podlaha, O. G.; Bruckschen, P.; Jasper, T., et al. 1997. Strontium isotope stratigraphy: potential resolution and event correlation. Palaeogeogr. Palaeoclimatol. Palaeoecol. 132:65-77.

Weedon, G. P., and Jenkyns, H. C. 1999. Cyclostratigraphy and the Early Jurassic timescale: data from the Belemnite Marls, southern England. Geol. Soc. Am. Bull. 111:1823-1840.

Wei, W. 1994. Age conversion table for different time scales. J. Nannoplankton Res. 16:71-73.

Young, G. C., and Laurie, J. R. 1996. An Australian Phanerozoic timescale. England, Oxford University Press.

Zachos, J. C.; Berggren, W. A.; Aubry, M.-P.; and Mackensen, A. 1992. Isotopic and trace element geochemistry of Eocene and Oligocene foraminifers from site 748, Kerguelen Plateau. Proc. Ocean Drilling Program Sci. Results 120:839-854.

Zachos, J. C.; Opdyke, B. N.; Quinn, T. M.; Jones, C. E.; and Halliday, A. N. 1999. Early Cenozoic glaciation, Antarctic weathering, and seawater ${ }^{87} \mathrm{Sr} /{ }^{86} \mathrm{Sr}$ : is there a link? Chem. Geol. 161:165-180. 